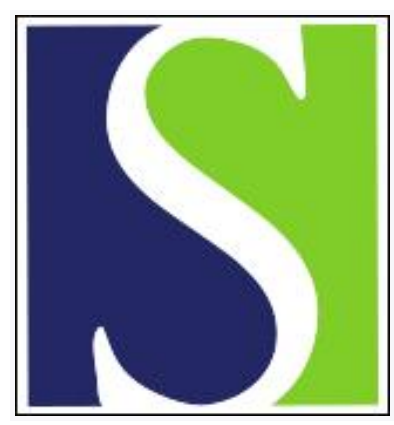

Scand J Work Environ Health 2002;28(4):270-277

https://doi.org/10.5271/sjweh.675

Issue date: Aug 2002

\title{
Occupation as a risk factor for uveal melanoma in Germany
}

by Monárrez-Espino J, Stang A, Bromen K, Merzenich H, Anastassiou G, Jöckel K-H

Affiliation: Insitute for Medical Informatics, Biometry and Epidemilogy, Hufelandstrasse 55, D-45122 Essen, Germany.

Refers to the following text of the Journal: 1996;22(1):14-26

The following article refers to this text: 2012;38(5):476-483

Key terms: case-control study; case-referent study; epidemiology; eye neoplasms; Germany; hospital-based study; occupation; occupational exposure; population-based study; risk factor; uveal melanoma

This article in PubMed: www.ncbi.nlm.nih.gov/pubmed/12199429 


\title{
Occupation as a risk factor for uveal melanoma in Germany
}

\author{
by Joel Monárrez-Espino, MD, ${ }^{1}$ Andreas Stang, MD, ${ }^{1}$ Katja Bromen, PhD, ${ }^{1}$ Hiltrud Merzenich, PhD, ${ }^{2}$ \\ Gerasimos Anastassiou, MD, ${ }^{3}$ Karl-Heinz Jöckel, PhD ${ }^{1}$
}

\begin{abstract}
Monárrez-Espino J, Stang A, Bromen K, Merzenich H, Anastassiou G, Jöckel K-H. Occupation as a risk factor for uveal melanoma in Germany. Scand J Work Environ Health 2002;28(4):270-277.
\end{abstract}

\begin{abstract}
Objective This study explored occupational risks linked to uveal melanoma.
Methods The analysis pooled data from two case-referent studies (hospital- and population-based) conducted in Germany between 1995 and 1998, with incident cases matched with several referents by age, gender, and region of residence. The subjects were contacted through personal or telephone interviews. Their exposure status was based on their occupational history. Dichotomous coding for the main task and categorization into different occupational classification systems was performed. Altogether of 118 cases and 475 referents were included. Adjusted odds ratios were calculated by conditional logistic regression.

Results Relevant occupations included food, beverage, and tobacco processors [odds ratio (OR) 4.7, 95\% confidence interval (95\% CI) 0.99-22.0] and miners (OR 2.3, 95\% CI 0.92-5.99) among the men and station, engine and heavy equipment operators and freight handlers (OR 2.5, 95\% CI 0.94-6.58) and medical, dental, pharmaceutical and veterinary workers (OR 2.1, 95\% CI 0.71-6.02) among the women according to the International Standard Classification of Occupations, whereas, according to the European Industrial Classification, the relevant occupations were the food industry (OR 3.4, 95\% CI 1.08-10.5) and the chemical and pharmaceutical industry (OR 2.8, 95\% CI 1.01-7.78) among the men and machine production (OR 3.2, 95\% CI $0.96-10.7$ ) and health and veterinary sector (OR 2.4, 95\% CI 0.97-5.71) among the women.
\end{abstract}

Conclusions These analyses support the potential role of occupational exposure as a risk factor for uveal melanoma. The findings must be interpreted carefully since the exposure was assessed indirectly.

Key terms case-control studies, case-referent studies, epidemiology, eye neoplasms, hospital-based, occupational exposure, population-based.

Uveal melanoma is a rare malignant tumor that occurs almost exclusively during adulthood (1-3). Although difficulties in diagnosing and classifying ocular melanomas have been reduced (4-7), the rates of metastasis and mortality remain unchanged, and survival has not improved substantially (8-11). Accordingly, identifying the risk factors has been a research priority for primary prevention.

Potential risk factors have been explored, ranging from demographic and host factors to environmental and occupational factors. Occupational exposure has been sought, as various rare cancers are caused by exposures occurring in the workplace (12). Occupations involving welding (13-17), farming (13, 14, 18-24), and exposure to chemicals $(13,25,26)$ have been the most frequently mentioned. However, no causative agent has been established, and contradictory evidence is common.

Recently, Stang et al (27) reported a positive link between exposure to radio frequency radiation and uveal melanoma based on the same case-referent studies presented in our present report, and Guenel et al (17) found an elevated risk among male welders in the French data

1 Institute for Medical Informatics, Biometry and Epidemiology, Medical Faculty, University of Essen, Essen, Germany. 2 Bremen Institute for Prevention Research and Social Medicine, Bremen, Germany.

3 Eye Clinic, Division of Ophthalmology, University of Essen, Essen, Germany.

Reprint requests to: Dr Andreas Stang, Institute for Medical Informatics, Biometry and Epidemiology, Hufelandstrasse 55, D-45122 Essen, Germany. [E-mail: andreas.stang@medizin.uni-essen.de] 
of the same European study on occupational causes of rare cancers from which the German part was extracted to be included in this analysis.

This paper presents a pooled analysis from two similarly designed case-referent studies conducted in Germany from 1995 to 1998 and aimed at exploring workrelated risks potentially linked to uveal melanoma. All ethical, legal, and medical confidentiality aspects were considered. The involved participants provided informed consent, and the data collected were held strictly in confidence.

\section{Subjects and methods}

Between 1995 and 1997, Germany and other European countries participated in a multinational populationbased case-referent study on occupational risk factors for eight rare cancers, including uveal melanoma. The German study area comprised five geographic regions covering a population of nearly 4 million inhabitants at risk.

During the fieldwork for the European study, an additional hospital-based case-referent study, limited to the German federal state of North Rhine-Westphalia, was carried out at the Eye Clinic, University of Essen, using the same questionnaires and personnel. This hospital is a referral center for eye tumors, and 250-300 uveal melanoma patients are treated there every year.

\section{Selection of cases}

For the population study, potentially eligible cases were patients with primary incident uveal melanoma located in the choroid or ciliary body. Other eligibility criteria included patient's age (35-69 years), place of residency, and date at diagnosis (1 July 1995 - 31 December 1997). An active reporting system from clinical and pathological departments within the study regions was set up to retrieve cases. Personal interviews (exceptionally by telephone) were conducted. A reference pathologist reviewed all the clinical and pathological reports, as well as specimens when available, to confirm the diagnosis. From the 47 observed cases, 44 were eligible for the study, and interviews were conducted with 37 patients, resulting in a response proportion of 84\% (28). The reasons for nonparticipation were refusals and inability to contact cases, $11 \%$ and $5 \%$ of the eligible cases, respectively.

In the hospital study, patients with incident primary uveal melanoma diagnosed between 1 December1996 and 31 March1998, aged 35-74 years, who were residents of North Rhine-Westphalia were eligible. Diagnoses were confirmed histologically for those who underwent surgery. Mostly personal, but also telephone, interviews were conducted. From the 99 cases diagnosed during the 16-month recruitment period, 92 patients were eligible for the study, and 81 were actually interviewed (response proportion of $88 \%$ ). Refusals were the main reason for nonparticipation, accounting for $8 \%$ of the eligible cases.

Since the city of Essen was covered by both studies, the cases from the Eye Clinic with residence in Essen were included in the population study during the 13month overlapping period (1 December 1996 - 31 December 1997).

\section{Selection of referents}

In the population study, referents were matched by age (5-year intervals), gender, and region of residency (Hamburg, Bremen, Essen, Saarbrücken, and Saarland). The referents were randomly selected from mandatory lists of residence, which cover the total population of the local districts and are regarded as the most complete sampling frame for population-based studies in Germany (29). The number of referents was determined by the stratum-specific maximum number of any of the rare cancers included in the study. Although a minimum of four referents per case in each stratum was foreseen, the matching resulted in ratios for the uveal melanoma study of up to 10 referents per case, as other cancers were more common than uveal melanoma. Of the eligible referents who were invited to participate, 699 agreed to do so, resulting in a response proportion of $48 \%$. The main reasons for nonparticipation were refusal and inability to contact persons, $31 \%$ and $8 \%$ of the eligible referents, respectively. Most of the participating referents were interviewed personally. Altogether 372 interviewed referents matched to cancers other than uveal melanoma were excluded from the analysis.

In the hospital study referents were also matched by age (5-year intervals), gender, and region of residency (Ruhr Area, south North Rhine-Westphalia $<100$ 000, south North Rhine-Westphalia $\geq 100000$, north North Rhine-Westphalia $<100000$, and north North RhineWestphalia $\geq 100000$ inhabitants). The selection of potential referents was based on the active reporting system established at the Eye Clinic. Eligible referents were patients with newly diagnosed benign disease of the posterior eye segment visiting the clinic during the same period as the cases. The major diagnoses of the referents were retinal detachment and defects (32\%), degeneration of the macula (18\%), retinal vascular occlusion (14\%), diabetic retinopathy (10\%), and others (26\%). No referent had suffered from occupational accidents involving the eye. Of the 248 potential referents, 187 were eligible for the study, and 148 were interviewed, the result being a response proportion of $79 \%$. Refusals 
and inability to contact were the most frequent reasons for nonparticipation, accounting for $13 \%$ and $4 \%$ of the eligible referents, respectively. Both personal and telephone interviews were carried out with the referents. Additional details of the case and referent selection have been published elsewhere (27).

\section{Exposure assessment and coding}

The evaluation of the exposure was based on the lifetime occupational history. A work biography was constructed for each participant of the study. All the jobs with a duration of at least 6 months were chronologically recorded. Within each job period, the duty consuming most of the person's worktime was defined as the "main task", and all others as classified were "secondary tasks".

The recorded jobs were classified into 34 "job groups" according to the International Standard Classification of Occupations (ISCO) (30) and also into 36 "industrial branches" according to the General Industrial Classification of Economic Activities within the European Communities (NACE) (31). In addition, at the end of the standard interview, a checklist with 30 different occupational groups was filled out. If the respondent ever worked in one or more of these groups, a jobspecific questionnaire, which has proved useful in classifying occupations in previous epidemiologic studies $(32,33)$, was applied. All the occupational categories utilized by these classification systems consisted of predetermined and fixed categories that were not modified or adjusted for the purpose of this study.

The interviewers were unaware of the study hypotheses as they administered the structured questionnaires. Each interview took approximately 70 minutes (median). The status of the cases and referents was unknown during the coding process. A different person conducted a second coding to assure the quality of the data. Comparisons between the first and second coding were made, and, if inconsistencies were found, a definitive coding was assigned based on a consensus.

\section{Statistical analyses}

Conditional logistic regression analyses were utilized to estimate the adjusted odds ratios (OR) and 95\% confidence intervals (95\% CI) (34). Dichotomous categorization for being exposed to the occupational category in question for the "main task" according to ISCO, NACE, and the checklist of the job-specific questionnaire was used to determine the exposure status. Estimates are presented only for the occupational categories with $\geq 5$ cases. Both descriptive analyses and conditional logistic regression analyses were performed with $\mathrm{SAS}^{\circledR}$ (35).

\section{Results}

Most of the tumors involved the choroid (98\%). Table 1 presents the characteristics of the cases and referents stratified by study design. The pooled analysis included 118 cases and 475 referents. The proportion of face-toface interviews was higher in the population study than in the hospital study. There was a skewed gender distribution among the population reference responders ( $72.5 \%$ men, $27.5 \%$ women). The educational background, measured as the number of school years, and smoking status were similar for the cases and referents in both studies.

Table 2 presents the risks by occupational groups according to the ISCO. For the men, food, beverage and tobacco processors (OR 4.7, 95\% CI 0.99-22.0) and miners (OR 2.3, 95\% CI 0.92-5.99) showed the highest risks. For the women, the risks were highest for station, engine and heavy equipment operators and freight handlers (OR 2.5, 95\% CI 0.94-6.58) and medical, dental, pharmaceutical and veterinary workers (OR 2.1, 95\% CI 0.71-6.02).

The risks are presented by industrial branches in table 3 according to the NACE. The odds ratios were the highest for the men working in the food industry (OR $3.4,95 \% \mathrm{CI} 1.08-10.5)$ and chemical and pharmaceutical industry (OR 2.8, 95\% CI 1.01-7.78), and for women in machine production (OR 3.2, 95\% CI 0.96-10.7) and the health and veterinary sector (OR 2.4, 95\% CI 0.97-5.71).

Table 4 shows the odds ratios by occupational category according to the job-specific questionnaire. The most relevant associations were found for cooking (OR 5.6, 95\% CI 1.66-19.19) among the men and health care (OR 2.1, 95\% CI 0.71-6.02) among the women.

No relevant negative associations were found for either classification system. Table 5 shows the consistency between the hospital and population studies for five selected occupational categories for the men and women together. Although some occupational categories had very few observations, the estimates pointed towards the same direction in both studies for chemical, farming, food, and mining.

\section{Discussion}

The lack of clear answers from prior studies indicated that a strong association with any work-related exposure was unlikely. Nevertheless, some occupational categories appeared to be positively linked to uveal melanoma.

Men working with food showed the highest risks in the three classifications. The study by Guenel et al (17) 
Table 1. Comparison of the cases and referents with respect to selected characteristics, with stratification by study design. ${ }^{\text {a }}$

\begin{tabular}{|c|c|c|c|c|c|c|c|c|c|c|c|c|}
\hline \multirow[b]{3}{*}{ Characteristic } & \multicolumn{4}{|c|}{ Population-based study } & \multicolumn{4}{|c|}{ Hospital-based study } & \multicolumn{4}{|c|}{ Pooled analysis } \\
\hline & \multicolumn{2}{|c|}{ Cases } & \multicolumn{2}{|c|}{ Referents } & \multicolumn{2}{|c|}{ Cases } & \multicolumn{2}{|c|}{ Referents } & \multicolumn{2}{|c|}{ Cases } & \multicolumn{2}{|c|}{ Referents } \\
\hline & $\mathrm{N}$ & $\%$ & $\mathrm{~N}$ & $\%$ & $\mathrm{~N}$ & $\%$ & $\mathrm{~N}$ & $\%$ & $\mathrm{~N}$ & $\%$ & $\mathrm{~N}$ & $\%$ \\
\hline \multicolumn{13}{|l|}{ Type of interview } \\
\hline $\begin{array}{l}\text { Face-to-face } \\
\text { Telephonic } \\
\text { Other }\end{array}$ & $\begin{array}{r}33 \\
4 \\
0\end{array}$ & $\begin{array}{c}89.2 \\
10.8 \\
0\end{array}$ & $\begin{array}{r}302 \\
21 \\
4\end{array}$ & $\begin{array}{r}92.4 \\
6.4 \\
1.2\end{array}$ & $\begin{array}{r}57 \\
21 \\
3\end{array}$ & $\begin{array}{r}70.4 \\
25.9 \\
3.7\end{array}$ & $\begin{array}{r}82 \\
66 \\
0\end{array}$ & $\begin{array}{r}55.4 \\
44.6 \\
0\end{array}$ & $\begin{array}{r}90 \\
25 \\
3\end{array}$ & $\begin{array}{r}76.3 \\
21.2 \\
2.5\end{array}$ & $\begin{array}{r}384 \\
87 \\
4\end{array}$ & $\begin{array}{r}80.9 \\
18.3 \\
0.8\end{array}$ \\
\hline \multicolumn{13}{|l|}{ Gender } \\
\hline $\begin{array}{l}\text { Male } \\
\text { Female }\end{array}$ & $\begin{array}{l}20 \\
17\end{array}$ & $\begin{array}{l}54.1 \\
45.9\end{array}$ & $\begin{array}{r}237 \\
90\end{array}$ & $\begin{array}{l}72.5 \\
27.5\end{array}$ & $\begin{array}{l}39 \\
42\end{array}$ & $\begin{array}{l}48.1 \\
51.9\end{array}$ & $\begin{array}{l}76 \\
72\end{array}$ & $\begin{array}{l}51.4 \\
48.6\end{array}$ & $\begin{array}{l}59 \\
59\end{array}$ & $\begin{array}{l}50.0 \\
50.0\end{array}$ & $\begin{array}{l}313 \\
162\end{array}$ & $\begin{array}{l}65.9 \\
34.1\end{array}$ \\
\hline \multicolumn{13}{|l|}{ Age distribution } \\
\hline $\begin{array}{l}35-44 \text { years } \\
45-54 \text { years } \\
55-64 \text { years } \\
65-74 \text { years }{ }^{\text {b }}\end{array}$ & $\begin{array}{r}4 \\
7 \\
15 \\
11\end{array}$ & $\begin{array}{l}10.8 \\
18.9 \\
40.5 \\
29.8\end{array}$ & $\begin{array}{r}85 \\
57 \\
113 \\
72\end{array}$ & $\begin{array}{l}26.0 \\
17.4 \\
34.6 \\
22.0\end{array}$ & $\begin{array}{l}12 \\
13 \\
32 \\
24\end{array}$ & $\begin{array}{l}14.8 \\
16.1 \\
39.5 \\
29.7\end{array}$ & $\begin{array}{l}13 \\
25 \\
63 \\
47\end{array}$ & $\begin{array}{r}8.8 \\
16.9 \\
42.6 \\
31.8\end{array}$ & $\begin{array}{l}16 \\
20 \\
47 \\
35\end{array}$ & $\begin{array}{l}13.6 \\
16.9 \\
39.8 \\
29.6\end{array}$ & $\begin{array}{r}98 \\
82 \\
176 \\
119\end{array}$ & $\begin{array}{l}20.6 \\
17.2 \\
37.1 \\
25.0\end{array}$ \\
\hline \multicolumn{13}{|l|}{ Schooling } \\
\hline $\begin{array}{l}<10 \text { years } \\
10-11 \text { years } \\
12-13 \text { years } \\
\text { Other }\end{array}$ & $\begin{array}{r}23 \\
7 \\
7 \\
0\end{array}$ & $\begin{array}{c}62.2 \\
18.9 \\
18.9 \\
0\end{array}$ & $\begin{array}{r}186 \\
72 \\
60 \\
9\end{array}$ & $\begin{array}{r}56.9 \\
22.0 \\
18.3 \\
2.8\end{array}$ & $\begin{array}{r}51 \\
9 \\
18 \\
3\end{array}$ & $\begin{array}{r}63.0 \\
11.1 \\
22.2 \\
3.7\end{array}$ & $\begin{array}{r}90 \\
27 \\
28 \\
3\end{array}$ & $\begin{array}{r}60.8 \\
18.2 \\
18.9 \\
2.0\end{array}$ & $\begin{array}{r}74 \\
16 \\
25 \\
3\end{array}$ & $\begin{array}{r}62.7 \\
13.6 \\
21.2 \\
2.5\end{array}$ & $\begin{array}{r}276 \\
99 \\
88 \\
12\end{array}$ & $\begin{array}{r}58.1 \\
20.8 \\
18.5 \\
2.5\end{array}$ \\
\hline \multicolumn{13}{|l|}{ Smoking status } \\
\hline $\begin{array}{l}\text { None } \\
\text { Mild } \\
\text { Moderate } \\
\text { Heavy }\end{array}$ & $\begin{array}{r}15 \\
7 \\
5 \\
10\end{array}$ & $\begin{array}{l}40.6 \\
18.9 \\
13.5 \\
27.0\end{array}$ & $\begin{array}{r}129 \\
57 \\
73 \\
68\end{array}$ & $\begin{array}{l}39.5 \\
17.4 \\
22.3 \\
20.8\end{array}$ & $\begin{array}{l}32 \\
17 \\
16 \\
16\end{array}$ & $\begin{array}{l}39.6 \\
21.0 \\
19.7 \\
19.7\end{array}$ & $\begin{array}{l}77 \\
32 \\
17 \\
22\end{array}$ & $\begin{array}{l}52.0 \\
21.6 \\
11.5 \\
14.9\end{array}$ & $\begin{array}{l}47 \\
24 \\
21 \\
26\end{array}$ & $\begin{array}{l}39.8 \\
20.4 \\
17.8 \\
22.0\end{array}$ & $\begin{array}{r}206 \\
89 \\
90 \\
90\end{array}$ & $\begin{array}{l}43.4 \\
18.8 \\
18.9 \\
18.9\end{array}$ \\
\hline
\end{tabular}

a Number of interviewed subjects: 37 cases and 327 referents in the population-based study, 81 cases and 148 referents in the hospital-based study, and 118 cases and 475 referents in the pooled analysis.

${ }^{b}$ For the population-based study only 65-69 years.

Table 2. Subject distribution, odds ratios $(\mathrm{OR})$ and $95 \%$ confidence intervals $(95 \% \mathrm{Cl})$ for uveal melanoma by occupational groups according to the International Standard Classification of Occupations (ISCO) in the pooled analyses and the gender of the subjects.

\begin{tabular}{|c|c|c|c|c|c|c|c|c|}
\hline \multirow[b]{2}{*}{ Gender a } & \multicolumn{2}{|c|}{ Cases } & \multicolumn{2}{|c|}{ Referents } & \multicolumn{2}{|c|}{ Unadjusted } & \multicolumn{2}{|c|}{ Adjusted $^{b}$} \\
\hline & $\mathrm{N}$ & $\%$ & $\mathrm{~N}$ & $\%$ & $\mathrm{OR}$ & $95 \% \mathrm{Cl}$ & $\mathrm{OR}$ & $95 \% \mathrm{Cl}$ \\
\hline \multicolumn{9}{|l|}{ Male } \\
\hline Architect, engineers, air-ship craft workers, production supervisors & 10 & 16.9 & 61 & 19.5 & 0.8 & $0.40-1.76$ & 0.8 & $0.36-1.73$ \\
\hline Jurists, teachers, scientists, other professional specialists & 6 & 10.2 & 26 & 8.3 & 1.2 & $0.49-3.18$ & 1.1 & $0.39-3.23$ \\
\hline Managers, managerial employees & 16 & 27.1 & 86 & 27.5 & 1.0 & $0.53-1.83$ & 1.1 & $0.56-2.23$ \\
\hline Clerical workers & 17 & 28.8 & 57 & 18.2 & 1.8 & $0.97-3.41$ & 1.8 & $0.86-3.78$ \\
\hline Sales workers & 8 & 13.6 & 40 & 12.8 & 1.1 & $0.47-2.42$ & 1.0 & $0.40-2.43$ \\
\hline Service workers & 8 & 13.6 & 34 & 10.9 & 1.3 & $0.56-2.93$ & 1.4 & $0.57-3.45$ \\
\hline General farmers & 7 & 11.9 & 15 & 4.8 & 2.7 & $1.04-6.84$ & 1.7 & $0.60-4.95$ \\
\hline Miners & 10 & 16.9 & 21 & 6.7 & 2.8 & $1.26-6.35$ & 2.3 & $0.92-5.99$ \\
\hline Food, beverage, tobacco processors & 5 & 8.5 & 5 & 1.6 & 4.5 & $1.16-17.0$ & 4.7 & $0.99-22.0$ \\
\hline Woodworkers & 5 & 8.5 & 26 & 8.3 & 1.0 & $0.38-2.78$ & 0.9 & $0.29-2.55$ \\
\hline Machinery fitters-assemblers, precision-instrument workers & 7 & 11.9 & 49 & 15.7 & 0.7 & $0.31-1.69$ & 0.8 & $0.34-2.07$ \\
\hline Plumbers, welders, sheet-structural metal workers & 6 & 10.2 & 45 & 14.4 & 0.7 & $0.27-1.66$ & 0.7 & $0.27-1.85$ \\
\hline Bricklayers, roofers, other construction workers & 12 & 20.3 & 42 & 13.4 & 1.6 & $0.81-3.35$ & 1.3 & $0.57-2.98$ \\
\hline Transport equipment operators & 11 & 18.6 & 42 & 13.4 & 1.5 & $0.71-3.07$ & 1.5 & $0.66-3.23$ \\
\hline \multicolumn{9}{|l|}{ Female } \\
\hline Medical, dental, pharmaceutical, veterinary workers & 8 & 13.6 & 10 & 6.2 & 2.4 & $0.89-6.32$ & 2.1 & $0.71-6.02$ \\
\hline Jurists, teachers, scientists, other professional specialists & 6 & 10.2 & 15 & 9.3 & 1.1 & $0.41-3.00$ & 1.1 & $0.40-3.30$ \\
\hline Managers, managerial employees & 11 & 18.6 & 32 & 19.8 & 0.9 & $0.44-1.99$ & 0.8 & $0.36-1.81$ \\
\hline Clerical workers & 19 & 32.2 & 53 & 32.7 & 1.0 & $0.52-1.84$ & 0.9 & $0.42-1.80$ \\
\hline Sales workers & 16 & 27.1 & 53 & 32.7 & 0.8 & $0.40-1.48$ & 0.7 & $0.34-1.44$ \\
\hline Service workers & 27 & 45.8 & 61 & 37.7 & 1.4 & $0.76-2.55$ & 1.8 & $0.86-3.80$ \\
\hline General farmers & 5 & 8.5 & 9 & 5.6 & 1.6 & $0.51-4.88$ & 1.4 & $0.41-4.78$ \\
\hline Spinners, weavers, textile workers, upholsterers & 9 & 15.3 & 24 & 14.8 & 1.0 & $0.45-2.37$ & 1.1 & $0.46-2.66$ \\
\hline Jewelers, musical instrument and other production workers & 6 & 10.2 & 6 & 3.7 & 2.9 & $0.91-9.43$ & 2.3 & $0.68-7.99$ \\
\hline Station, engine, heavy equipment operators, freight handlers & 9 & 15.3 & 12 & 7.4 & 2.2 & $0.89-5.62$ & 2.5 & $0.94-6.58$ \\
\hline
\end{tabular}

a Only occupational categories with $\geq 5$ cases were included for each gender.

${ }^{\mathrm{b}}$ The conditional logistic regression model included age and region of residence. 
Table 3. Subject distribution, odds ratios (OR), and $95 \%$ confidence intervals $(95 \% \mathrm{Cl})$ for uveal melanoma by industrial branches according to the European Industrial Classification of Occupations (NACE) in the pooled analyses and the gender of the subjects.

\begin{tabular}{|c|c|c|c|c|c|c|c|c|}
\hline \multirow[b]{2}{*}{ Gender a } & \multicolumn{2}{|c|}{ Cases } & \multicolumn{2}{|c|}{ Referents } & \multicolumn{2}{|c|}{ Unadjusted } & \multicolumn{2}{|c|}{ Adjusted ${ }^{b}$} \\
\hline & $\mathrm{N}$ & $\%$ & $\mathrm{~N}$ & $\%$ & $\mathrm{OR}$ & $95 \% \mathrm{Cl}$ & $\mathrm{OR}$ & $95 \% \mathrm{Cl}$ \\
\hline \multicolumn{9}{|l|}{ Male } \\
\hline Agriculture, forestry, hunting, fishing & 7 & 11.9 & 23 & 7.3 & 1.7 & $0.69-4.14$ & 1.4 & $0.51-3.60$ \\
\hline Mining & 11 & 18.6 & 31 & 9.9 & 2.1 & $0.98-4.41$ & 1.9 & $0.81-4.66$ \\
\hline Food industry & 7 & 11.9 & 12 & 3.8 & 3.4 & $1.27-8.91$ & 3.4 & $1.08-10.5$ \\
\hline Chemical and pharmaceutical industry & 9 & 15.3 & 15 & 4.8 & 3.6 & $1.48-8.55$ & 2.8 & $1.01-7.78$ \\
\hline Office goods manufacturing, electro and precision working & 6 & 10.2 & 24 & 7.7 & 1.4 & $0.53-3.49$ & 1.9 & $0.62-5.96$ \\
\hline Wholesale trading and intermediates & 6 & 10.2 & 32 & 10.2 & 1.0 & $0.40-2.49$ & 1.3 & $0.49-3.54$ \\
\hline Retail trading & 6 & 10.2 & 33 & 10.5 & 1.0 & $0.38-2.40$ & 0.8 & $0.27-2.26$ \\
\hline Transport & 9 & 15.3 & 43 & 13.7 & 1.1 & $0.52-2.46$ & 1.4 & $0.58-3.22$ \\
\hline Landed property services, business services & 8 & 13.6 & 39 & 12.5 & 1.1 & $0.49-2.49$ & 0.8 & $0.34-2.08$ \\
\hline \multicolumn{9}{|l|}{ Female } \\
\hline Agriculture, forestry, hunting, fishing & 6 & 10.2 & 14 & 8.6 & 1.2 & $0.44-3.26$ & 1.1 & $0.39-3.25$ \\
\hline Textile production, manufacturing & 10 & 16.9 & 21 & 13.0 & 1.4 & $0.60-3.10$ & 1.6 & $0.66-3.93$ \\
\hline Paper, editorial and printing industry & 5 & 8.5 & 11 & 6.8 & 1.3 & $0.42-3.81$ & 1.8 & $0.55-5.71$ \\
\hline Machine production & 6 & 10.2 & 8 & 4.9 & 2.2 & $0.72-6.52$ & 3.2 & $0.96-10.7$ \\
\hline Office goods manufacturing, electro and precision working & 5 & 8.5 & 13 & 8.0 & 1.1 & $0.36-3.11$ & 1.3 & $0.40-3.89$ \\
\hline Wholesale trading and intermediates & 10 & 16.9 & 17 & 10.5 & 1.7 & $0.75-4.03$ & 1.7 & $0.68-4.31$ \\
\hline Retail tradings & 18 & 30.5 & 55 & 34.0 & 0.9 & $0.45-1.62$ & 0.8 & $0.41-1.64$ \\
\hline Catering trade & 8 & 13.6 & 12 & 7.4 & 2.0 & $0.76-5.04$ & 2.3 & $0.85-6.19$ \\
\hline Landed property services, business services & 11 & 18.6 & 17 & 10.5 & 1.9 & $0.86-4.44$ & 2.1 & $0.83-5.40$ \\
\hline Health and veterinary sector & 12 & 20.3 & 16 & 9.9 & 2.3 & $1.03-5.24$ & 2.4 & $0.97-5.71$ \\
\hline House making & 12 & 20.3 & 26 & 16.0 & 1.3 & $0.62-2.85$ & 1.3 & $0.64-3.50$ \\
\hline
\end{tabular}

a Only occupational categories with $\geq 5$ cases were included for each gender.

${ }^{b}$ The conditional logistic regression model included age and region of residence.

Table 4. Subject distribution, odds ratios (OR), and 95\% confidence intervals $(95 \% \mathrm{Cl})$ for uveal melanoma by occupational category according to the job-specific questionnaire classification in the pooled analyses and the gender of the subjects.

\begin{tabular}{|c|c|c|c|c|c|c|c|c|}
\hline \multirow[b]{2}{*}{ Gender a } & \multicolumn{2}{|c|}{ Cases } & \multicolumn{2}{|c|}{ Referents } & \multicolumn{2}{|c|}{ Unadjusted } & \multicolumn{2}{|c|}{ Adjusted ${ }^{b}$} \\
\hline & N & $\%$ & N & $\%$ & $\mathrm{OR}$ & $95 \% \mathrm{Cl}$ & $\mathrm{OR}$ & $95 \% \mathrm{Cl}$ \\
\hline \multicolumn{9}{|l|}{ Male } \\
\hline Cooking & 6 & 10.2 & 8 & 2.6 & 4.3 & $1.44-12.8$ & 5.6 & $1.66-19.1$ \\
\hline Farming & 7 & 11.9 & 21 & 6.7 & 1.9 & $0.76-4.61$ & 1.4 & $0.50-3.77$ \\
\hline Working with farm animals & 6 & 10.2 & 14 & 4.5 & 2.4 & $0.89-6.54$ & 1.5 & $0.47-4.54$ \\
\hline Welding, brazing, soldering & 13 & 11.9 & 101 & 32.3 & 0.6 & $0.31-1.15$ & 0.9 & $0.43-1.76$ \\
\hline Builder, stonemason, plasterer & 14 & 16.9 & 46 & 14.7 & 1.8 & $0.92-3.54$ & 1.4 & $0.64-2.99$ \\
\hline Chemical industry & 5 & 8.5 & 15 & 4.8 & 1.8 & $0.64-5.25$ & 1.9 & $0.57-6.34$ \\
\hline Metal working & 11 & 18.6 & 101 & 32.3 & 0.5 & $0.24-0.97$ & 0.6 & $0.30-1.29$ \\
\hline \multicolumn{9}{|l|}{ Female } \\
\hline Health care & 9 & 15.2 & 16 & 9.9 & 1.6 & $0.68-3.93$ & 2.1 & $0.71-6.02$ \\
\hline Cooking & 11 & 18.6 & 29 & 17.9 & 1.1 & $0.49-2.26$ & 1.1 & $0.40-3.30$ \\
\hline Farming & 6 & 10.2 & 15 & 9.3 & 1.1 & $0.41-3.00$ & 0.8 & $0.36-1.81$ \\
\hline Working with farm animals & 5 & 8.5 & 13 & 8.0 & 1.1 & $0.36-3.11$ & 0.9 & $0.42-1.80$ \\
\hline
\end{tabular}

a Only categories with $\geq 5$ cases were included for each gender.

b The conditional logistic regression model included age and region of residence.

also showed a high risk for uveal melanoma among male cooks, and Vågerö et al (36) reported an increased proportional registration ratio for ocular melanoma for female "kitchen hands" (36). Cooking fumes may be responsible for the higher risk, or, alternatively, exposure to radiation from microwaves, strong light from incandescent ovens, or infrared radiation as has been postulated by Guenel et al (17).

Various studies have found increased risks for farmers $(14,18-21)$ and chemical workers $(13,25,26)$. Yet 
Table 5. Consistency of the adjusted odds ratios between the population $(\mathrm{P})$ and hospital $(\mathrm{H})$ case-referent studies for the International Standard Classification of Occupations (ISCO), the European Industrial Classification of Occupations (NACE), and the job-specific questionnaire classification (JSQ) for both genders. (Adj OR = adjusted odds ratio, Ref = referents)

\begin{tabular}{|c|c|c|c|c|c|c|c|c|c|c|c|c|c|c|c|c|c|c|}
\hline \multirow{3}{*}{$\begin{array}{l}\text { Occupational } \\
\text { category }\end{array}$} & \multicolumn{6}{|c|}{ ISCO } & \multicolumn{6}{|c|}{ NACE } & \multicolumn{6}{|c|}{ JSQ } \\
\hline & \multicolumn{3}{|c|}{ Population } & \multicolumn{3}{|c|}{ Hospital } & \multicolumn{3}{|c|}{ Population } & \multicolumn{3}{|c|}{ Hospital } & \multicolumn{3}{|c|}{ Population } & \multicolumn{3}{|c|}{ Hospital } \\
\hline & Cases & Ref & Adj $0 R^{a}$ & Cases & Ref & Adj $\mathrm{OR}^{\mathrm{a}}$ & Cases & Ref & Adj $O R^{a}$ & Cases & Ref & Adj OR ${ }^{a}$ & Cases & Ref & Adj $0 \mathrm{R}^{\mathrm{a}}$ & Cases & Ref & Adj OR \\
\hline Chemical b & No $\mathrm{ca}$ & ases & & 3 & 2 & 3.0 & 4 & 12 & 2.8 & 8 & 11 & 1.6 & No ca & ses & & 5 & 4 & 4.0 \\
\hline Farming ${ }^{c}$ & 2 & 14 & 1.1 & 10 & 10 & 1.8 & 3 & 20 & 1.4 & 10 & 17 & 1.2 & 2 & 20 & 0.8 & 11 & 16 & 1.3 \\
\hline Food d & 1 & 5 & 2.5 & 3 & 3 & 2.8 & 4 & 26 & 1.1 & 7 & 9 & 1.5 & 5 & 21 & 2.0 & 12 & 16 & 2.2 \\
\hline Mining ${ }^{e}$ & 4 & 13 & 2.9 & 6 & 10 & 1.5 & 5 & 19 & 3.1 & 7 & 15 & 1.2 & . & . & $\cdot$ & . & . & . \\
\hline Health ${ }^{\dagger}$ & 4 & 14 & 2.7 & 5 & 9 & 0.8 & 2 & 18 & 0.7 & 10 & 16 & 1.2 & 4 & 18 & 1.8 & 6 & 11 & 0.9 \\
\hline
\end{tabular}

a The conditional logistic regression model included age and region of residence.

${ }^{b}$ Chemical, rubber and plastic workers (ISCO); chemical and pharmaceutical industry (NACE); chemical industry (JSQ).

c General farmers (ISCO); agriculture, forestry, hunting and fishing (NACE); farming (JSQ).

${ }^{d}$ Food, beverage and tobacco processors (ISCO); food industry (NACE); cooking (JSQ).

e Miners (ISCO); mining (NACE); no mining category (JSQ).

i Medical, dental, pharmaceutical and veterinary workers (ISCO); health and veterinary sector (NACE); health care (JSQ).

these analyses showed nonsignificantly elevated risks for workers in the chemical industry and farmers consistently across classifications.

Miners or mining also had increased risks. However, one study made reference to "miners, quarrymen" and found no elevated risks whatsoever (36).

In our study, the occupational categories that included welders did not show positive associations, as mentioned before $(13,15-17)$. Given that the proportion of welders in the study base was too small for an independent analysis, welders were dichotomized as having ever welded, but still no association was found (OR 1.3, 95\% CI 0.6-2.5).

The highest risks for women were found for "station, engine, and heavy equipment operators and freight handlers" (ISCO) and "machine production" (NACE). Elevated risks for women working in "bus and truck services" and "fabricated metal products manufacturing" have been documented for eye cancer in a study from the United States among women in the workplace (37). Guenel et al (17) also showed increased risks among female "metal workers" and "material handling operators".

Women working in health care presented consistently high risks across the three classifications employed. This finding has also been previously reported $(13,38)$ and has been thought to be the result of referral bias (13).

The low response rate of the referents in the population study, a problem frequently faced in Germany (29), limited the interpretation of the results. Biased estimates could have occurred if nonparticipation were associated with a higher prevalence of exposure to occupations. Selection bias cannot be ruled out since meaningful comparisons between participating and non- participating referents could not be made because very few nonparticipating referents filled out the short questionnaire designed for this purpose.

The skewed gender distribution of the population reference responders was the result of the matching effect rather than a selection bias. The proportion of male referents was larger in the population study because the reference group was used for several rare cancers and its size was determined by the most frequent cancer in each stratum (eg, testicular cancer).

Another limitation relates to the exposure assessment, as it relied on an indirect source with which to infer the exposure status for individual persons. Occupational title was utilized as a surrogate for exposure. We used the ISCO and NACE classifications, as they allow a more-or-less precise identification of the work done by the workers, and by inference of the risks involved, and because they are major references for international comparisons. The degree to which the misclassification of recalled job periods and occupations could have occurred was largely related to the complexity of the individual persons' occupational histories. To reduce this complexity, we attempted to conduct personal interviews. The overall proportion of face-to-face interviews in the pooled analyses was $76.3 \%$ and $80.9 \%$ for the cases and referents, respectively.

Although misdiagnosis may have occurred for the nonhistologically confirmed cases, the rate of false-positive diagnoses has been reported to be as low as $0.5 \%$ when done in experienced centers $(5,39)$, such as in those involved on this study.

The analyses were able to replicate findings from earlier investigations. For instance, the risk of uveal melanoma was significantly higher for persons with light-color eyes than it was for those with dark-color 
eyes (OR 2.9, 95\% CI 1.5-5.6), as previously reported $(10,36,40)$. This finding supports the trustworthiness of the presented results.

The consistency between studies was assessed by comparing the odds ratios for five relevant occupational groups according to the revised literature. Except for health, most of the estimates pointed in the same direction. Although it was not possible to stratify the results by gender due to sample size constraints, these findings also enhanced the validity of the results.

The relatively small number of cases and the dilution of the effect by pooling jobs in an occupational category could have been responsible for the lack of statistical significance. In addition, with a nondifferential misclassification of the exposure status in a dichotomous variable, a bias towards the null is expected to occur and lead to lack of significant results. Conversely, multiple testing might have induced a bias raising the likelihood that some associations could have appeared by chance.

\section{Acknowledgments}

This study was partially supported by a grant from the Federal Ministry of Education and Research, Germany (Bundesministerium für Bildung und Forschung-BMBF, no 01HP 684/8).

We gratefully acknowledge the collaboration with the European Study Group on Occupational Causes of Rare Cancers: Denmark: Herman Autrup, Henrik Kolstad, Linda Kaerlev, Elsebeth Lynge, Jorn Olsen, Lisbeth Norum Pedersen, Svend Sabroe, (reference pathologists: Preben Johansen, Stein Poulsen, Peter Stubbe Teglbjaerg, Mogens Vyberg); France: Pascal Guénel, Joëlle Févotte, Diane Cyr, and the members of the FRANCIM association (Patrick Arveux, Antoine Buemi, Paule-Marie Carli, Gilles Chaplain, Jean-Pierre Daurès, Jean Faivre, Pascale Grosclaude, Anne-Valérie Guizard, Michel Henry-Amar, Guy Launoy, Francois Ménégoz, Nicole Raverdy, Paul Schaffer); Germany: Wolfgang Ahrens, Cornelia Baumgardt-Elms, Sibylle Gotthardt, Ingeborg Jahn, Karl-Heinz Jöckel, Hiltrud Merzenich, Andreas Stang, Christa Stegmaier, Antje Timmer, Hartwig Ziegler, Katja Bromen; Italy: Terri Ballard, Franco Bertoni, Giuseppe Gorini, Sandra Gostinicchi, Giovanna Masala, Enzo Merler, Franco Merletti, Lorenzo Simonato, Paola Zambon; Latvia: Irena Rogovska, Galina Sharkova, Aivars Stengrevics; Lithuania: Jolita Gibaviciene, Laimonas Jazukevicius, Juozas Kurtinaitis, Poma Pociute; Portugal: Noemia Alfonso, Altamiro Costa-Pereira, Sonia Doria, Carlos Lopes, José Manuel Lopes, Ana Miranda, Cristina Santos; Spain: Adela Sanz Aguado, Juan J. Aurrekoetxea, Concepción Brun, Alicia Córdoba, Miguel Angel Martínez
González, Francisco Guillén Grima, Rosa Guarch, Agustin Llopis González, Blanca Marín, Amparo Marquina, María M Morales Suárez-Varela, Inés Aguinaga Ontoso, JM Martínez Peñuela, Ana Puras, Francisco Vega, Maria Aurora Villanueva Guardia; Sweden: Mikael Eriksson, Lennart Hardell, Irene Larsson, Hakan Olson, Monica Sandström, Gun Wingren; Switzerland: Jean-Michel Lutz; United Kingdom: Janine Bell, Ian Cree, Tony Fletcher, Alex JE Foss.

\section{References}

1. Mork T. Malignant neoplasms of the eye in Norway: incidence, treatment and prognosis. Acta Ophthalmol1 961; 39:824-31.

2. Jensen OA. Malignant melanomas of the uvea in Denmark 1943-1952: a clinical, histopathological and prognostic study. Acta Ophthalmol 1963;75:17-78.

3. Raivio I. Uveal melanoma in Finland: an epidemiological, clinical, histological and prognostic study. Acta Ophthalmol Suppl 1977;133:1-64.

4. Shields JA. Modern methods in the diagnosis of uveal melanomas. Trans Ophthalmol Soc UK 1977;97:407-11.

5. Collaborative Ocular Melanoma Study (COMS) Group. Accuracy of diagnosis of choroidal melanomas in the Collaborative Ocular Melanoma Study. Arch Ophthalmol 1990;108:1268-73.

6. Gamel JW, McLean IW. Quantitative analysis of the Callender classification of uveal melanoma cells. Arch Ophthalmol 1977;95:686-91.

7. McLean IW, Foster WD, Zimmerman LE, Gamel JW. Modifications of Callender's classification of uveal melanoma at the Armed Forces Institute of Pathology. Am J Ophthalmol 1983;96:502-9.

8. Hakulinen T, Teppo L, Saxen E. Cancer of the eye, a review of trends and differentials. World Health Stat Q 1978;31:14358.

9. Strickland D, Lee JA. Melanomas of eye: stability of rates. Am J Epidemiol 1981;113:700-2.

10. Jensen OA. Malignant melanomas of the human uvea: 25year follow-up of cases in Denmark, 1943-1952. Acta Ophthalmol 1982;60:161-82.

11. Frisch M, Olsen JH. Survival of Danish cancer patients 1943 1987: eye, brain and nervous system, thyroid, bone and connective tissue. APMIS Suppl 1993;33:156-82.

12. Althouse R, Huff J, Tomatis L, Wilbourn J. Chemicals and industrial processes associated with cancer in humans. In: International Agency for Research on Cancer (IARC). IARC monographs, volumes 1 to 20. Lyon: IARC, 1979:1-71. IARC monographs on the evaluation of the carcinogenetic risk of chemicals on humans, suppl 1.

13. Holly EA, Aston DA, Ahn DK, Smith AH. Intraocular melanoma linked to occupations and chemical exposures. Epidemiology 1996;7:55-61.

14. Ajani U, Seddon JM, Hsieh C, Egan KM, Albert DM, Gragoudas ES. Occupation and risk of uveal melanoma: an exploratory study. Cancer 1992;70:2891-900.

15. Tucker MA, Shields JA, Hartge P, Augsburger J, Hoover RN, Fraumeni JF Jr. Sunlight exposure as risk factor for 
intraocular malignant melanoma. N Engl J Med 1985;313: 789-92.

16. Seddon JM, Gragoudas ES, Glynn RJ, Egan KM, Albert DM, Blitzer PH. Host factors, UV radiation, and risk of uveal melanoma: a case-control study. Arch Ophthalmol 1990; 108:1274-80.

17. Guenel P, Laforest L, Cyr D, Fevotte J, Sabroe S, Dufour C, et al. Occupational risk factors, ultraviolet radiation, and ocular melanoma: a case control study in France. Cancer Causes Control 2001;12:451-9.

18. Saftlas AF, Blair A, Cantor KP, Hanrahan L, Anderson HA. Cancer and other causes of death among Wisconsin farmers. Am J Ind Med. 1987;11:119-29.

19. Lynge E, Thygesen L. Occupational cancer in Denmark: cancer incidence in the 1970 census population. Scand J Work Environ Health 1990;16 suppl 2:1-35.

20. Doll R. Urban and rural factors in the aetiology of cancer. Int J Cancer 1991;47:803-10.

21. Keller JE, Howe HL. Case-control studies of cancer in Illinois farmers using data from the Illinois State Cancer Registry and the US census of agriculture. Eur J Cancer 1994; 30:469-73.

22. Wiklund K, Dich J. Cancer risks among male farmers in Sweden. Eur J Cancer Prev 1995;4:81-90.

23. Kristensen P, Andersen A, Irgens LM, Laake P, Bye AS. Incidence and risk factors of cancer among men and women in Norwegian agriculture. Scand J Work Environ Health 1996;22:14-26.

24. Pukkala E, Notkola V. Cancer incidence among Finish farmers 1979-93. Cancer Causes Control 1997;8:25-33.

25. Albert DM, Puliafito CA, Fulton AB, Robinson NL, Zakov $\mathrm{ZN}$, Dryja TP, et al. Increased incidence of choroidal malignant melanoma occurring in a single population of chemical workers. Am J Ophthalmol 1980;89(3):323-37.

26. Enterline PE, Hartley J, Henderson V. Asbestos and cancer: a cohort followed up to death. Br J Ind Med 1987;44:396-401.

27. Stang A, Anastassiou G, Ahrens W, Bromen K, Bornfeld N, Jöckel KH. The possible role of radiofrequency radiation in the development of uveal melanoma. Epidemiology 2001;12:7-12.

28. Slattery ML, Edwards SL, Caan BJ, Kerber RA, Potter JD. Response rates among control subjects in case-control studies. Ann Epidemiol 1995;5:245-9.

29. Stang A, Ahrens W, Jöckel KH. Control response proportions in population-based case-control studies in Germany.
Epidemiology.1999;10:181-3.

30. International Labour Office. International standard classification of occupations (ISCO). Revised edition. Geneva: International Labour Office, 1968.

31. Statistical Office of the European Communities. Nomenclature Générale des activités Economiques dans la CEE (NACE): general industrial classification of economic activities within the European communities. Brussels: Statistical Office of the European Communities, 1985.

32. Jöckel KH, Ahrens W, Wichmann HE, Becher H, BolmAudorff U, Jahn I, Molik B, Greiser E, Timm J. Occupational and environmental hazards associated with lung cancer. Int $\mathbf{J}$ Epidemiol 1992;21:202-13.

33. Jöckel KH, Ahrens W, Jahn I, Pohlabeln H, Bolm-Audorff U. Bundesanstalt für Arbeitsmedizin. Untersuchungen zu Lungenkrebs und Risiken am Arbeitsplatz. 1 Ed. Bremerhaven: Wirtschaftsverlag NW. Schriftenreihe der Bundesanstalt für Arbeitsmedizin, 1995.

34. Breslow NE, Day NE. Statistical methods in cancer research; vol 1 (The analysis of case-control studies). Lyon: International Agency for Research on Cancer (IARC), 1980. IARC scientific publications, no 32 .

35. SAS Institute. Changes and enhancements through release 6.11. Cary (NC): SAS Institute, 1996.

36. Vågerö D, Swerdlow AJ, Beral V. Occupation and malignant melanoma: a study based on cancer registration data in England and Wales and in Sweden. Br J Ind Med 1990;47:31724.

37. Swanson GM. Burns PB. Cancer incidence among women in the workplace: a study on the association between occupation and industry and 11 cancer sites. J Occup Environ Med 1995;37:282-7.

38. Pukkala E. Cancer risk by social class and occupation: a survey of 109,000 cancer cases among Finns of working age. Tampere: Finnish Cancer Registry and School of Public Health, University of Tampere, 1995:90-2.

39. Mukai S, Gragoudas ES. Diagnosis of choroidal melanoma. In: Albert J, Jakobiec A, editors. Principles and practice of ophthalmology; vol 5. 1994:3209-45.

40. Holly EA, Aston DA, Char DH, Kristiansen JJ, Ahn DK. Uveal melanoma in relation to ultraviolet light exposure and host factors. Cancer Res 1990;50:5773-7.

Receved for publication: 7 December 2001 